\title{
April Fools- sell-side analysts discover biotechnology
}

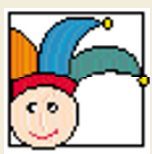

Tom Jacobs, of the Internet site Motley Fool (http://www. fool.com/), provides his angle on biotechnology investments. $\mathrm{He}$ can be contacted at TomJ@ Fool.com, but he can't give individual investment advice.

The leading players in this season's soap opera, "As Enron Turns," are the Wall Street analysts who continued to recommend Enron stock as it crashed into oblivion, and in the process Pied-Pipered many individual investors to ruin. Now, these analysts are turning their attention to companies within the biotechnology universe, providing a flood of new coverage announcements (see Table 1). But beware their melodic charms! We must equip ourselves to avoid being lured into the same sad fate as Enron investors.

By "analyst" I mean the analysts at the international investment banks such as Goldman Sachs, Bear Stearns, Merrill Lynch, Morgan Stanley Dean Witter, Lehman Brothers, and Prudential. In one corner are the investment bankers who earn huge fees by helping their clients raise money by selling stock or issuing debt, or by executing their mergers and acquisitions. In the other are the banks' research analysts, whose job purportedly is to support the banks' brokerage sales operations. The latter operators are called sell-side analysts, and they issue recommendations and price targets for the stocks they follow.

\section{Analysts don't want you}

You will often see the sell-sider on CNBC and the Bloomberg channel where he-and it is almost always a he-trumpets his company's "buy," "sell," or "hold" recommendation and the price target for shares in his client's company. To demonstrate the sell-sider's seemingly superhuman ability to influence the company's stock price, he will be accompanied by a chart showing its movements of the share price. In living rooms around the world, you can almost hear the awe-inspired cry: "Look,

Nature Biotechnology does not guarantee the veracity, reliability, or completeness of any information provided on this page; it is not responsible for any errors or omissions or for any results obtained from the use of such information; it will not be liable for any loss, damage, or investment decision arising from a reader's reliance on the information provided.
Hortense, Mr. Joe Armani Suit's words just moved Consolidated Widgets' price up 20 cents!" Joe Armani Suit's recommendations and targets are reported and tabulated in all financial media — broadcast, print, and Webwhich happily showcase the star to hook viewers and readers.

But don't be fooled. Joe Armani Suit wants attention not to help you and me invest in the stock market for long-term profit, but to promote his employer's investment banking services. Not surprisingly, clients companies are much more likely to favor a bank that publicly praises their business. During the heyday of new companies using the Internet as a platform for their businesses, analysts such as Henry Blodget and Mary Meeker became financial media stars. They ballyhooed Amazon, eBay, and others in every forum possible, and their employers made hundreds of millions of dollars handling huge stock and debt offerings for those e-commerce companies. Blodget and Meeker made millions, too, and reduced their price targets - if at all-only long after the companies' stock prices had plummeted. Now, many banks see biotechnology as the next frontier and are hiring analysts to chase the new business. Look out.

\section{Analyst ethics}

Officially, a wall is supposed to exist between an investment bank's research and banking operations, but there is no escaping the inherent conflict of interest. Banking fees, not brokerage commissions, pay the big bucks. If a sell-side analyst knows that his bonus at the end of the year depends on how well the investment bank has performed overall, he will do what it takes to bring in and maintain the most profitable business. So he will issue a lot of positive recommendations and high price targets for companies with current and poten- tial business for the investment banking side.

For this reason alone, individual investors can be sure that if a sell-side analyst issues anything other than a "strong buy" or even a "buy" recommendation, the bank is not expecting to get much business from that company-either the bank has been frozen out of deals before, the bank works for a competitor, or the company's prospects are so dire that the bank has no hope of future business in the company's bankruptcy reorganization. Sad to say, that last slim hope was probably one reason that many Enron analysts hung on, issuing recommendations that harmed individual investors.

\section{Be safe, be cynical}

When you see that an analyst at Gray Beard Bank awards Genes-R-Us a "strong buy" recommendation and a price target of triple whatever it is now, ignore it. Although you might learn something about the business from a very critical reading of a good sell-side analyst's report, you will learn nothing from the recommendation and the target. You might also be lucky enough to obtain research from analysts who work for large institutions such as mutual funds (elsewhere referred to as unit trusts) and pension funds, which buy (rather than sell) stocks and have no investment banking or sales operations. These buy-side analysts have none of the conflicts of the sell-siders, but their work is rarely made public.

Sell-side analysts have little interest in you, dear reader; they are interested in getting publicity to drum up new business. Their research may be helpful or not, but their recommendations and targets should come with a health warning on the label. Share investment learning with friends, family, and your investment club. Regulation and legislation of analysts may come one day, but we can start to protect ourselves today. Until next month, stay Foolish!
Table 1. New analyst coverage-Biotechnology, February 2002 Company Recommendation Price target

Abgenix (Fremont, CA)

Myriad Genetics (Salt Lake City, UT)

Medarex (Princeton, NJ)

Buy, $\$ 50$

Sell, $\$ 25$

Buy, $\$ 25$

Millennium Pharmaceuticals (Cambridge, MA)

Celera Genomics (Rockville, MD)

Tularik (S. San Francisco, CA)

Human Genome Sciences (Rockville, MD)

Zymogenetics (Seattle, WA)

ICOS Corporation (Bothell, WA)

Cubist Pharmaceuticals (Cambridge, MA)

Gilead Sciences (Foster City, CA)

Trimeris (Durham, NC)
Buy, $\$ 38$

Buy, $\$ 33$

Hold, \$22

Hold, \$28

Various

Sector perform, $\$ 52$

Sector perform, $\$ 23$

Sector perform, $\$ 81$

Sector perform, \$54
Investment bank

Prudential

Prudential

Prudential

Prudential

Prudential

Prudential

Prudential

Various

RBC Capital Markets RBC Capital Markets RBC Capital Markets RBC Capital Markets 